\title{
ALARA-elv alkalmazásával jelentősen csök- kenthető a katéterablációs kezelések során használt ionizáló röntgensugárzás mennyisége
}

\author{
Piros Katalin, Herczeg Szilvia, Szegedi Nándor, Salló Zoltán, Osztheimer István, \\ Széplaki Gábor, Tahin Tamás, Nagy Klaudia Vivien, Perge Péter, \\ Bettenbuch Tünde, Srej Mariann, Merkely Béla, Gellér László
}

Semmelweis Egyetem, Városmajori Szív- és Érgyógyászati Klinika, Budapest

Levelezési cím: Dr. Piros Katalin, e-mail: piroskati90@gmail.com

Bevezetés: Elektrofiziológiai vizsgálat és katéterabláció során a fluoroszkóp használata a katéterek valós időben való ábrázolásához szükséges lehet. Az ionizáló sugárzás sztochasztikus módon is okozhat egészségkárosodást, ilyenkor az ok-okozati összefüggések nem mindig állapíthatóak meg pontosan. Az utóbbi idöben komoly eröfeszítések történtek a sugáridő csökkentése irányában (ALARA: as low as reasonably achievable). Az irodalomban különböző centrumok esetében a sugáridő, valamint a felhasznált sugárdózis között jelentős különbségek vannak.

Célkitüzés: A különböző elektrofiziológiai beavatkozások során jelenleg felhasznált sugáridő összehasonlítása a 2014 előtti adatokkal.

Módszer: A Városmajori Szív- és Érgyógyászati Klinikán 2016.10.06-2017.01.10., valamint 2013.10.18-2013.12.16. között végzett elektrofiziológiai beavatkozások során regisztrált sugáridők feldolgozását, összehasonlítását végeztük el. Eredmények: Pitvarfibrilláció, pitvari flutter, AVRT, AVNRT, VES-abláció, valamint elektrofiziológiai vizsgálat esetén jelenleg az átlagosan használt sugáridő Klinikánkon jelentősen kevesebb, mint 2014 előtt (5,57 vs. 13,9 perc $p<0,0001$; 2,24 vs. 6,41 perc $p=0,0078 ; 3,32$ vs. 7,74 perc $p=0,0211 ; 1,7$ vs. 5,16 perc $p<0,0001 ; 2,17$ vs. 5,83 perc $p=0,0006 ; 0,68$ vs. 1,43 perc $p=0,0378$ ).

Következtetés: Klinikánkon az ALARA elv alkalmazásával a 3 évvel ezelőtti adatokhoz képest lényegesen kevesebb a röntgensugár használata az elektrofiziológiai vizsgálatok és katéterablációk során, amely a nemzetközi adatokkal összevetve is impresszív.

Kulcsszavak: ALARA, elektrofiziológia, sugáridő

With the implementation of ALARA principles the fluoroscopy time can be reduced in a high progressivity center Introduction: Fluoroscopic real-time visualization of the catheters may be needed during electrophysiological studies and catheter ablations. Radiation can cause health damage in a stochastic way as well, the cause-effect relations cannot always be determined. Lately serious efforts have been done to reduce the fluoroscopy time and dose, as required by the ALARA (as low as reasonably achievable) concept. In the literature, the radiation time and radiation dose vary among different clinical centers.

Aim: Our aim was to compare the mean fluoroscopic time used during electrophysiological procedures nowadays and before 2014

Method: We collected and compared the fluoroscopy times registered between 06 October 2016 and 10 January 2017. and 18 October 2013 and 16 December 2013 at the Heart and Vascular Center of Semmelweis University.

Results: We observed a significantly lower mean fluoroscopy time in the case of atrial fibrillation, atrial flutter, AVRT, AVNRT, PVC ablation and electophysiological studies compared to the procedures before 2014 (5,57 vs. 13,9 min $p<0,0001 ; 2,24$ vs. $6,41 \min p=0,0078 ; 3,32$ vs. $7,74 \min p=0,0211 ; 1,7$ vs. $5,16 \min p<0,0001 ; 2,17$ vs. $5,83 \min p=0,0006$; 0,68 vs. $1,43 \min p=0,0378$ ).

Conclusion: Over three years with the use of ALARA priciples we obtained a significantly lower mean fluoroscopy time during electrophysiologiacal studies and catheter ablations, which is impressive compared with the international literature.

Keywords: ALARA, electrophysiology, fluoroscopy time 


\section{Bevezetés}

Az orvosi célokra alkalmazott ionizáló sugárzás menynyisége mind az egészségügyi személyzet, mind a beteg szempontjából kiemelkedő jelentőséggel bír ismert szövetkárosító hatása miatt. Napjainkban különösen fontos a téma, hiszen az orvostudomány fejlődésével a minimál invazív beavatkozások száma ugrásszerü, folyamatos növekedést mutat, ennek megfelelöen a közelmúltban jelentősen megnövekedett az ionizáló sugarat alkalmazó, invazív kardiovaszkuláris beavatkozások száma is $(1,2)$. Ugyanakkor a technikai fejlödésnek köszönhetően egyre összetettebb beavatkozásokat tudunk végezni (3-7). A nemzetközi irodalom is kiemelt figyelmet fordít az orvosi beavatkozások során használt ionizáló sugárzás okozta lehetséges károsodások feltárására, és ezen ártalmak megelőzésére, amely elsősorban tudatos sugárhasználattal érhető el.

A sugárkárosodásnak ismert determinisztikus hatása, miszerint egy adott, ún. küszöbdózis után biztosan kialakul sugárkárosodás, amely a küszöbdózis felett arányosan nő a sugárzás mennyiségével. A használt sugárdózis hatásai azonban nem mindig mérhetőek pontosan. A sugárzás sztochasztikus hatását jelenti, hogy habár a sugárterheléssel emelkedik a károsodás valószínüsége, a károsodás minősége, súlyossága nem függ a dózistól. A sugárterhelés mérésére a közölt dózist (KAP vagy DAP) használjuk, mivel a sugáridő a tényleges sugárterhelésről kevésbé ad pontos információt. A sztochasztikus hatás becslésére az effektív dózist használjuk, amely a DAP segítségével számítható egy fix szorzótényező használatával (8). Kiemelt jelentőséggel bír a legkisebb sugárterheléssel járó beavatkozás is, hiszen jelen tudásunk szerint a malignus daganatok kialakulására egy biztos küszöbdózis nem jósolható meg (sztochasztikus hatás) (9). Megfigyelték, hogy gyerekkorban, veleszületett szívhibák miatt végzett invazív kardiológiai kivizsgálásokat követően a bekövetkező kromoszóma-sérülések hosszú távon kimutathatóak (10). Egy amerikai retrospektív vizsgálat szerint a kardiológiai kivizsgáláson áteső egyének 9,5\%-ában használtak ionizáló sugárzást alkalmazó képalkotási módszert, amely során a három évre eső effektív dózis átlagosan 23,1 mSv (11). (Egy mellkasröntgen átlagosan 0,1 mSv.) Az elektrofiziológiai vizsgálatok és katéterablációs beavatkozások során használt sugárdózis 1-100 mSv között változhat, mely 50-5000 mellkas-röntgenvizsgálat okozta sugárterhelésnek felel meg (12). Daganatos megbetegedés kialakulásában a 10 mSv okozta rizikóhoz képest a $100 \mathrm{mSv}$ és az azt meghaladó sugárdózis tízszeres rizikónövekedést jelent az adott egyén élete folyamán (13). Kiemelendő, hogy egyes páciensek több alkalommal eshetnek át röntgensugárzást használó beavatkozáson, így az őket érő összesített effektív dózis halmozódik. Kimutatott tény, hogy a legfoglalkoztatottabb intervencionális kardiológusok évi sugárterhelése körülbelül $5 \mathrm{mSv}$, amely a radiológusok és nukleáris medicinában dolgozó orvosok által elszenvedett dózis háromszorosának felel meg (14).

2005-ben a szakmai kollégium irányelvet adott ki a kardiológiai képalkotásokra vonatkozóan, amely szerint (mint minden orvosi tevékenység esetében) a kockázat-haszon arány minden beavatkozás előtt mérlegelendő (14). A sugárterhelés az ALARA-elv („,as low as reasonably achievable”, azaz „olyan kevés, ami észszerűen elérhető") mindennapi gyakorlatba történő implementálásával jelentős mértékben csökkenthető (15). Mivel nem létezik teljes mértékben biztonságos mennyiségủ sugár, a lehető legkevesebb ionizáló sugár használatra kell törekednünk, mind a páciens, mind a személyzet sugárterhelésének mérséklése céljából (8). Ennek elérése érdekében különböző sugárvédelmi lehetőségek állnak rendelkezésünkre, mint a távolságvédelem, az idővédelem, a sugárzást gyengítő anyagok használata és a sugárforrás optimális beállitása. Szakirodalmi ajánlások is egyértelmüen alátámasztják, hogy a sugárdózis csökkenthetö a pulzatilis mód alkalmazásával, alacsony dózis beállításával, a kollimáció megfelelő használatával, védőpajzzsal, folyamatos dózisméréssel $(12,16)$. Háromdimenziós térképező rendszerek és intrakardiális echokardiográfia napi rutinba való beépítésével a sugárterhelés tovább csökkenthető, sőt egyes esetekben akár sugár nélkül is elvégezhető az abláció, úgynevezett „zéró fluoroszkópia” módszerrel (17). Ennek ellenére a 2015-ös „EORP” európai regiszter szerint a vizsgált centrumok kevés figyelmet fordítottak az ALARA alkalmazására a rendelkezésükre álló lehetőségek ellenére (18).

\section{Célkitữzés}

Retrospektív vizsgálatunk célja a Városmajori Szív- és Érgyógyászati Klinikán végzett elektrofiziológiai beavatkozások során az ALARA-elv bevezetését követően regisztrált sugáridő-, és sugárdózis-csökkenés megítélése és összehasonlítása a nemzetközi adatokkal.

\section{Módszerek}

Összegyüjtöttük a 2013. október és 2013. december, valamint 2016. október és 2017. január között végzett elektrofiziológiai beavatkozások során regisztrált sugáridőket és sugárdózisokat Klinikánk retrospektív adatbázisából. Mivel a 2013-as adatok esetében nem állt rendelkezésünkre DAP-érték, ezért a csak sugáridők összehasonlítására volt lehetőségünk. Ez azonban ugyanolyan informatív a sugárdózisra, mivel az Elektrofiziológiai Laborunkban használt sugárforrás beállításai a két időszak között nem változtak. Effektív dózis kiszámítására a szakirodalom szerinti 0,2-es szorzót használtuk. A statisztikai számításokat t-teszt- 
tel végeztük Graph Pad Prism 6.01 szoftver segítségével. Szignifikánsnak a $p<0,05$ értéket tekintettük.

\section{Eredmények}

A Városmajori Szív- és Érgyógyászati Klinikán három hónap alatt 2013. évben 194, míg 2016. évben 245 beavatkozás történt (1. táblázat). A sugáridő tekintetében jelentős csökkenést értünk el szinte minden típusú elektrofiziológiai beavatkozás esetében a három év alatt (2. táblázat). A pitvarfibrilláció abláció átlagos sugárideje átlag 14 percröl 6 percre csökkent. Konvencionális ablációk esetén ez a csökkenés még kifejezettebb volt: atrioventrikuláris reentry tachycardia (AVRT) esetében 8 percről 3 percre, míg atrioventrikuláris nodalis reentry tachycardia (AVNRT) esetén 5-ről 2 percre változott, pitvar flutter és elektrofiziológiai vizsgálat (EPS)

1. TÁBLÁZAT. A vizsgált időszakban végzett elektrofiziológiai vizsgálatok és ablációk száma. Rövidítések: $A V(N) R T$ : atrioventrikuláris (nodalis) reentry tachycardia, VES: kamrai extrasystole, VT: kamrai tachycardia, AT: pitvari tachycardia, EPS: elektrofiziológiai vizsgálat

\begin{tabular}{|l|c|c|}
$\begin{array}{l}\text { Elektrofiziológiai } \\
\text { beavatkozás/ } \\
\text { abláció }\end{array}$ & $\begin{array}{l}\text { Esetszám } \\
\text { (2013.10.18.- } \\
\mathbf{2 0 1 3 . 1 2 . 1 6 . )}\end{array}$ & $\begin{array}{l}\text { Esetszám } \\
\text { (2016.10.06.- } \\
\mathbf{2 0 1 7 . 0 1 . 1 0 . )}\end{array}$ \\
\hline Pitvarfibrilláció abláció & 78 & 120 \\
\hline Pitvari fluttern abláció & 17 & 30 \\
\hline AVNRT abláció & 25 & 38 \\
\hline AVRT abláció & 17 & 17 \\
\hline VES abláció & 19 & 16 \\
\hline VT abláció & 4 & 8 \\
\hline AT abláció & 5 & 15 \\
\hline EPS abláció & 29 & 10 \\
\hline
\end{tabular}

2. TÁBLÁZAT. Sugáridő átlagos hossza klinikánkon történt különböző elektrofiziológiai beavatkozások során. A 2013-as és 2016-os eredményeink összehasonlítása. Rövidítések: AV(N)RT: atrioventrikuláris (nodalis) reentry tachycardia, VES: kamrai extrasystole, VT: kamrai tachycardia, AT: pitvari tachycardia, EPS: elektrofiziológiai vizsgálat

\begin{tabular}{|l|c|c|r|}
\hline $\begin{array}{l}\text { Elektrofiziológi- } \\
\text { ai beavatkozás/ } \\
\text { abláció }\end{array}$ & $\begin{array}{l}\text { Fluoro idö } \\
\text { (min) 2013 } \\
(\mathbf{n = 1 9 4 )}\end{array}$ & $\begin{array}{l}\text { Fluoro idő } \\
\text { (min) 2016 } \\
\text { (n=245) }\end{array}$ & p-érték \\
\hline $\begin{array}{l}\text { Pitvarfibrilláció } \\
\text { abláció }\end{array}$ & 13,90 & 5,58 & $<0,0001$ \\
\hline Pitvari flutter abláció & 6,41 & 2,24 & 0,0078 \\
\hline AVRT-abláció & 7,74 & 3,32 & 0,0211 \\
\hline AVNRT-abláció & 5,16 & 1,70 & $<0,0001$ \\
\hline VES-abláció & 5,83 & 2,17 & 0,0006 \\
\hline VT-abláció & 17,00 & 7,50 & 0,2818 \\
\hline AT-abláció & 11,96 & 6,41 & 0,2195 \\
\hline EPS & 1,43 & 0,68 & 0,0378 \\
\hline
\end{tabular}

3. TÁBLÁZAT. 2016-ban klinikánkon regisztrált sugárdózis összehasonlítása szakirodalmi adatokkal. Rövidítések: AV(N)RT: atrioventrikuláris (nodalis) reentry tachycardia, AT: pitvari tachycardia, VT: kamrai tachycardia, EPS: elektrofiziológiai vizsgálat

\begin{tabular}{|l|l|l|}
\hline $\begin{array}{l}\text { Elektro- } \\
\text { fiziológiai } \\
\text { beavatkozás }\end{array}$ & $\begin{array}{l}\text { Effektív dózis a } \\
\text { szakirodalom- } \\
\text { ban (mSv) }\end{array}$ & $\begin{array}{l}\text { Effektív dózis } \\
\text { Klinikánkon 2016 } \\
\text { évben (mSv) }\end{array}$ \\
\hline Pitvarfibrilláció & $16,6(6,6-59,2)$ & $1,23(0,12-4,34)$ \\
\hline AVNRT, AVRT, AT & $4,4(1,6-25,0)$ & $1,15(0,10-5,22)$ \\
\hline VT & $12,5(3,0-45,0)$ & $0,61(0,02-1,54)$ \\
\hline EPS & $3,2(1,3-23,9)$ & $0,13(0,03-0,59)$ \\
\hline
\end{tabular}

esetében pedig felére csökkent. 2016-ra a kamrai extrasystolia (VES) abláció esetében harmadolódott a sugáridő a 2013-as adatainkhoz képest. A pitvari, illetve kamrai tachycardia ablációk esetén nem találtunk szignifikáns különbséget a két csoportot összehasonlítva, bár itt az esetszám igen alacsony volt.

Végül összehasonlítottuk a 2016 során történt elektrofiziológiai beavatkozások effektív dózisait a nemzetközi szakirodalmi adatokkal (6). Klinikánkon alkalmazott sugárterhelés számottevően kevesebbnek imponál (3. táblázat).

\section{Megbeszélés}

A kockázat-haszon arány megfelelő irányba billentése érdekében a pácienst, valamint a személyzetet érő sugárterhelés minimalizálása szükséges. Ehhez elengedhetetlen a szakszemélyzet megfelelő oktatása a sugárforrást biztosító berendezés által nyújtott dóziscsökkentő lehetőségekről (16). Az ALARA-elv három alappillére a következő:

- nincs biztonságos mennyiségű ionizáló sugárdózis,

- a dózis csökkentésével a mellékhatás rizikó csökken,

- valamint a többszöri sugárzás okozta sugárterhelés kumulálódik.

Jelentős dóziscsökkenés érhető el a sugáridő csökkentésével, optimálisan megválasztott kollimációval, a sugárforrás és sugárvevő ideális pozicionálásával, a besugárzott terület változtatásával (16). A beavatkozás során a sugárdózis rögzítése fontos visszajelzést nyújt az operatőr számára. Klinikánkon az ALARA-elvet 2014-ben kezdtük alkalmazni a következő elvek alapján: szükséges mennyiségủ sugáridő, frame rate csökkentés (pulzatilis mód 8 kép/s, felvételmód $12 \mathrm{kép} / \mathrm{s}$ ), kollimáció, védőpajzshasználat, távolságvédelem. Vizsgálatunk során jelentős sugárterhelés csökkenést regisztráltunk Klinikánkon az ALARA implementálása elötti adatokhoz képest a legtöbb abláció esetében. Pitvari, illetve kamrai tachycardia abláció esetében is sugáridő csökkenését figyeltünk meg, azonban az alacsony esetszám miatt statisztikai szignifikanciát nem találtunk a két eredmény között. Vizsgálatunk rávilágít a tényre, hogy tudatos odafigyelés esetén az ALARA 
könnyedén implementálható és számottevő sugárterhelés csökkenést nyújthat.

\section{Következtetések}

Klinikánkon szignifikánsan csökkent az alkalmazott ionizáló röntgensugárzás ideje a legtöbb elektrofiziológiai beavatkozás esetében. Az ALARA-elv fokozottabb előtérbe helyezésével az eredményt olyan beállításokkal értük el, mint pulzatilis mód, alacsony frame-rate, kollimálás használata. Emellett kiemelt jelentőséggel bírnak a mára már széles körben elterjedt egyéb képalkotók, úgymint elektroanatómiai térképező rendszer és intrakardiális echokardiográfia, amelyekkel még tovább tudjuk csökkenteni a sugárkárosodás valószínúségét.

\section{Irodalom}

1. Lucas FL, DeLorenzo MA, Siewers AE, et al Temporal trends in the utilization of diagnostic testing and treatments for cardiovascular disease in the United States, 1993-2001. Circulation 2006; 113(3): 374-9.10. 1161/CIRCULATIONAHA.105.560433

2. Geller L, Szilagyi S, Zima E et al Long-term experience with coronary sinus side branch stenting to stabilize left ventricular electrode position. Heart Rhythm 2011;8(6):845-50. 10.1016/j.hrthm.2011.01.016

3. Geller L, Szilagyi S, Zima E et al Successful epicardial ablation of a postinfarction ventricular tachycardia. Orv Hetil 2008; 149(49) 2335-9. 10.1556/OH.2008.28474

4. Osztheimer I, Szilagyi S, Geller L, et al. Minimal Invasive Left Ventricular Lead Repositioning is Safe and Effective in Distal Left Ventricular Lead Positions. Pacing Clin Electrophysiol 2017; 40(5): 488-93. 10.1111/pace.13068

5. Neuhoff I, Szilagyi S, Geller L, et al. Transseptal Leftventricular Endocardial Pacing is an Alternative Technique in Cardiac Resynchronization Therapy. One Year Experience in a High Volume Center. Rom J Intern Med 2016; 54(2): 121-8. 10. 1515/rjim-2016-0020 6. Szegedi N, Zima E, Geller L, et al. Radiofrequency ablation of focal atrial tachycardia: Benefit of electroanatomical mapping over conventional mapping. Acta Physiol Hung 2015; 102(3): 252-62. 10.1556/036.102.2015.3.3

7. Ozcan EE, Osztheimer I, Geller L, et al. Successful ablation of atrioventricular nodal re-entrant tachycardia in a patient with interruption of inferior vena cava and azygos continuation. Can J Cardiol 2013; 29(12): 1741 e9-11. 10.1016/j.cjca.2013.08.014

8. Pantos I, Patatoukas G, Katritsis DG, et al. Patient radiation doses in interventional cardiology procedures. Curr Cardiol Rev 2009; 5(1): 1-11. 10.2174/157340309787048059

9. Damjanovich Sándor FJ, Szöllösi J. Orvosi biofizika. Medicina Könyvkiadó Zrt.; 2007. p. 638.

10. Andreassi MG, Ait-Ali L, Botto N, et al. Cardiac catheterization and long-term chromosomal damage in children with congenital heart disease. Eur Heart J 2006; 27(22): 2703-8. 10.1093/eurheartj/ ehl014

11. Chen J, Einstein AJ, Fazel R, et al. Cumulative exposure to ionizing radiation from diagnostic and therapeutic cardiac imaging procedures: a population-based analysis. J Am Coll Cardiol 2010; 56(9): 702-11. 10.1016/j.jacc.2010.05.014

12. Picano E, Piccaluga E, Padovani R, et al. Risks Related To Fluoroscopy Radiation Associated With Electrophysiology Procedures. J Atr Fibrillation 2014; 7(2): 1044. 10.4022/jafib.1044

13. Venneri L, Rossi $F$, Botto $N$, et al. Cancer risk from professional exposure in staff working in cardiac catheterization laboratory: insights from the National Research Council's Biological Effects of Ionizing Radiation VII Report. Am Heart J 2009; 157(1): 118-24. 10.1016/j.ahj.2008.08.009

14. Brindis RG, Douglas PS, Hendel RC, et al. ACCF/ASNC appropriateness criteria for single-photon emission computed tomography myocardial perfusion imaging (SPECT MPI): a report of the American College of Cardiology Foundation Quality Strategic Directions Committee Appropriateness Criteria Working Group and the American Society of Nuclear Cardiology endorsed by the American Heart Association. J Am Coll Cardiol 2005; 46(8): 1587-605. 10.1016/j. acc.2005.08.029

15. National Council on Radiation Protection and Measurements NCoRPaMSC-oAfO-EliCR, National Council on Radiation Protection and Measurements. Scientific Committee 46 on Operational Radiation Safety. Implementation of the principle of as low as reasonably achievable (ALARA) for medical and dental personnel: recommendations of the National Council on Radiation Protection and Measurements: Bethesda, MD: NCRP; 1990.

16. Hirshfeld JW, Jr, Balter S, Brinker JA, et al. ACCF/AHA/HRS/ SCAI clinical competence statement on physician knowledge to optimize patient safety and image quality in fluoroscopically guided invasive cardiovascular procedures: a report of the American College of Cardiology Foundation/American Heart Association/ American College of Physicians Task Force on Clinical Competence and Training. Circulation 2005; 111(4): 511-32. 10.1161/01. CIR.0000157946.29224.5D

17. Bulava A, Hanis J, Eisenberger M. Catheter Ablation of Atrial Fibrillation Using Zero-Fluoroscopy Technique: A Randomized Trial. Pacing Clin Electrophysiol 2015; 38(7): 797-806. 10.1111/pace.12634 18. Estner HL, Grazia Bongiorni M, Chen J, et al Use of fluoroscopy in clinical electrophysiology in Europe: results of the European Heart Rhythm Association Survey. Europace 2015; 17(7): 1149-52. 10.1093/europace/euv223 